\title{
Waste Management Systems among Smallholder Farmers in Masaka and Lyantonde Districts, Central Uganda
}

\author{
Gerald Kamoga ${ }^{*}$, Charles Ssekyewa ${ }^{2}$ \\ ${ }^{1}$ Faculty of Agriculture, Uganda Martyrs University, Kampala, Uganda \\ ${ }^{2}$ St. Lawrence University, Kampala, Uganda \\ Email: ^gkamos0409@gmail.com
}

How to cite this paper: Kamoga, G. and Ssekyewa, C. (2021) Waste Management Systems among Smallholder Farmers in Masaka and Lyantonde Districts, Central Uganda. Journal of Agricultural Chemistry and Environment, 10, 314-326.

https://doi.org/10.4236/jacen.2021.103020

Received: May 25, 2021

Accepted: July 12, 2021

Published: July 15, 2021

Copyright () 2021 by author(s) and Scientific Research Publishing Inc. This work is licensed under the Creative Commons Attribution International License (CC BY 4.0).

http://creativecommons.org/licenses/by/4.0/

\begin{abstract}
With diversity in farming systems, crop residues, animal wastes and management practices are often not well managed, and most of it is left on the soil surface. This practice is common, especially among smallholder farmers (SHFs). There is no updated record of commonly used waste management practices. Our study focused on smallholder farmers in two farming systems in Masaka and Lyantonde Districts respectively, and with the objective to determine smallholder waste management practices in relation to farm waste components. Using a sample survey, quantitative data were collected from 120 SHFs representing $10.1 \%$ of the total SHF population in the Masaka while 120 SHFs provided data and represented $17.4 \%$ of the total SHF population in Lyantonde. Our result revealed that for animal waste, Goat slurry $20.4 \%$, dominated the rest in Lyantonde, while in Masaka Pig slurry 23.6\%, was dominant. For crop waste in Lyantonde, Bean trashes $12.9 \%$, dominated, while in Masaka Banana leaves and peelings $11.1 \%$, were dominant. In Lyantonde, common waste management practices were: Surface deposition $41.2 \%$, Burning $18.4 \%$ Composting 17.3\%, Burying 9.4\%, Removal 10.9\% and Recycling 2.8\%. In Masaka, common practices were: Surface deposition 40.9\%, Burning 18.6\% Composting 13.2\%, Burrying 12.3\%, Removal 6.2\% and Recycling 8.8\%. Factors affecting choice of waste management practices by SHFs were: Age, purpose of waste product, season, quantity of the wastes, waste management policy awareness, farmer's commitment and economic status of the farmer. Greenhouse gas emission for identified waste management practices across the two Districts shall be determined in our next study.
\end{abstract}

\section{Keywords}

Farm System, Farm Waste, Smallholder Farmer, Practice, Waste Management 


\section{Introduction}

Along the production chain, some crop and animal materials are regarded as waste. This is when such materials apparently seize to be valuable to the farmer. According to [1] off-farm wastes contribute $82.5 \%$ of household wastes. It is only those SHFs who still attach value to selected waste that goes ahead to sort and use or otherwise burn or abandon. Whether such materials have more value in some instances or not, this study considered all biodegradable waste generated at the smallholder farmer level. Such waste included but was not limited to: trash, peelings and slurry [2].

Smallholder farm waste management practices in relation to farm waste were also studied. The study finally looked at factors affecting the choice of waste management practices (WMP) by SHFs. In the study area, farm wastes were reported to be left in the fields or burned, and these practices were considered not suitable because of the associated emission of Carbon dioxide $\left(\mathrm{CO}_{2}\right)$, Nitrous oxide $\left(\mathrm{N}_{2} \mathrm{O}\right)$, Methane $\left(\mathrm{CH}_{4}\right)$ and Ammonia $\left(\mathrm{NH}_{3}\right)$ [3] .

Globally, [4] estimated 23\% of total anthropogenic greenhouse gas emissions in 2007-2016 to be derived from agriculture, forestry and other land use. These activities were reported to account for $13 \%$ of $\mathrm{CO}_{2}, 44 \%$ of methane $\left(\mathrm{CH}_{4}\right)$ [5], 2015; [6] [7] reported that emissions from the agricultural wastes had an average annual increase of $4 \%$.

Among activities that drive agriculture sector GHG emissions are livestock production, inefficient crop and animal waste management [8]. This justifies the anthropogenic global warming theory which informs this study on the ground that the emissions generated through poor waste management are anthropogenic and will continue to rise unless intercepted. The Waste Management Theory (WMT) has also been adopted because of its perspectives on waste and waste management. The theory offers scientifically adequate definitions of key concepts of waste management. The theory defines wastes basing on their four classes as reported by [9]. For example, [10] defined waste as residues from cultivation, livestock production and aquaculture which may contain materials that can benefit man. The theory proposes organization of diverse variables of waste management such as system components, farming systems, waste management practices, chemical composition of waste, time factor and temperature among others. The theory also assumes that the goal of waste management is to conserve resources and protect the environment [11]. The output of these two theories can be perfectly disseminated using three principles of the Social Learning Theory. These principles are observation, imitation and modelling [12].

Composting of agricultural waste or converting it into compost is considered as one of the most favorable, cheap, and simple methods used to treat and stabilize a different kind of waste as well as generating organic fertilizers.

The specific objectives of our study were: to determine system components regarded as waste by smallholder farmers; to determine farm waste management practices across the two farming systems; and to assess factors affecting choice of 
waste management practices among smallholder farmers in both farming systems.

\section{Methodology}

\subsection{The Study Area and Design}

We used a cross-sectional survey that utilized quantitative techniques of data collection to collect data on, system components regarded as waste by smallholder farmers, farm waste management practices and factors affecting choice of waste management practices among smallholder farmers in both farming systems.

This study was conducted in Masaka and Lyantonde Districts within Central Uganda. These Districts have been purposively selected due to the fact that they are inhabited by many smallholder farmers. According to a report by [13], Lyantonde District had a total population of 93,753 people and Masaka District had a total population of 297,004 people by 2014 . Farmers made $69 \%$ of total populations, while $65 \%$ of the total farming population was Smallholder Farmers in Masaka, and $78 \%$ in Lyantonde district. In the study area, agricultural production predominantly occurs at smallholder farms [14]. In these areas women carry a disproportionately higher labor burden [15] [16]. This creates labor shortage especially handling farm waste. All efforts are mainly directed towards food and economic stability of the household. Most men are taken up by off farm part-time jobs such as brick making, charcoal burning and trading. In addition, adoption of household composting and farm waste management is still low, and is positively influenced by social economic factors [17]. Farming characteristics of these two Districts by 2014 have been summarized in Table 1 [13].

Table 1. Farming characteristics of Masaka and Lyantonde Districts.

\begin{tabular}{ccccc}
\hline \multirow{2}{*}{ Household characteristic } & \multicolumn{2}{c}{ Lyantonde District } & \multicolumn{2}{c}{ Masaka District } \\
\cline { 2 - 4 } & Population & Percentage & Population & Percentage \\
\hline Livestock farming & 11,806 & 57.2 & 33,874 & 44.0 \\
Crop farming & 16,383 & 79.4 & 44,741 & 59.3 \\
Crop or livestock farming & 17,122 & 83.0 & 49.062 & 65.0 \\
\hline
\end{tabular}

Masaka District is more famous for its arable farming practices while Lyantonde is predominantly a mixed farming District. These Districts have a tropical climate with a bi-modal rainfall pattern ranging from $915 \mathrm{~mm}$ to $1800 \mathrm{~mm}$ per annum. The driest month is July, with $67 \mathrm{~mm}$ of rainfall. In April, the precipitation reaches its peak, with an average of $201 \mathrm{~mm}$. The mean annual rainfall is $1100 \mathrm{~mm}$ distributed over 106 rain days, with peaks in March-May and September-November. In recent years, due to climate variability and change, rainfall has been erratic.

MAP OF UGANDA SHOWING STUDY DISTRICTS (Figure 1) 


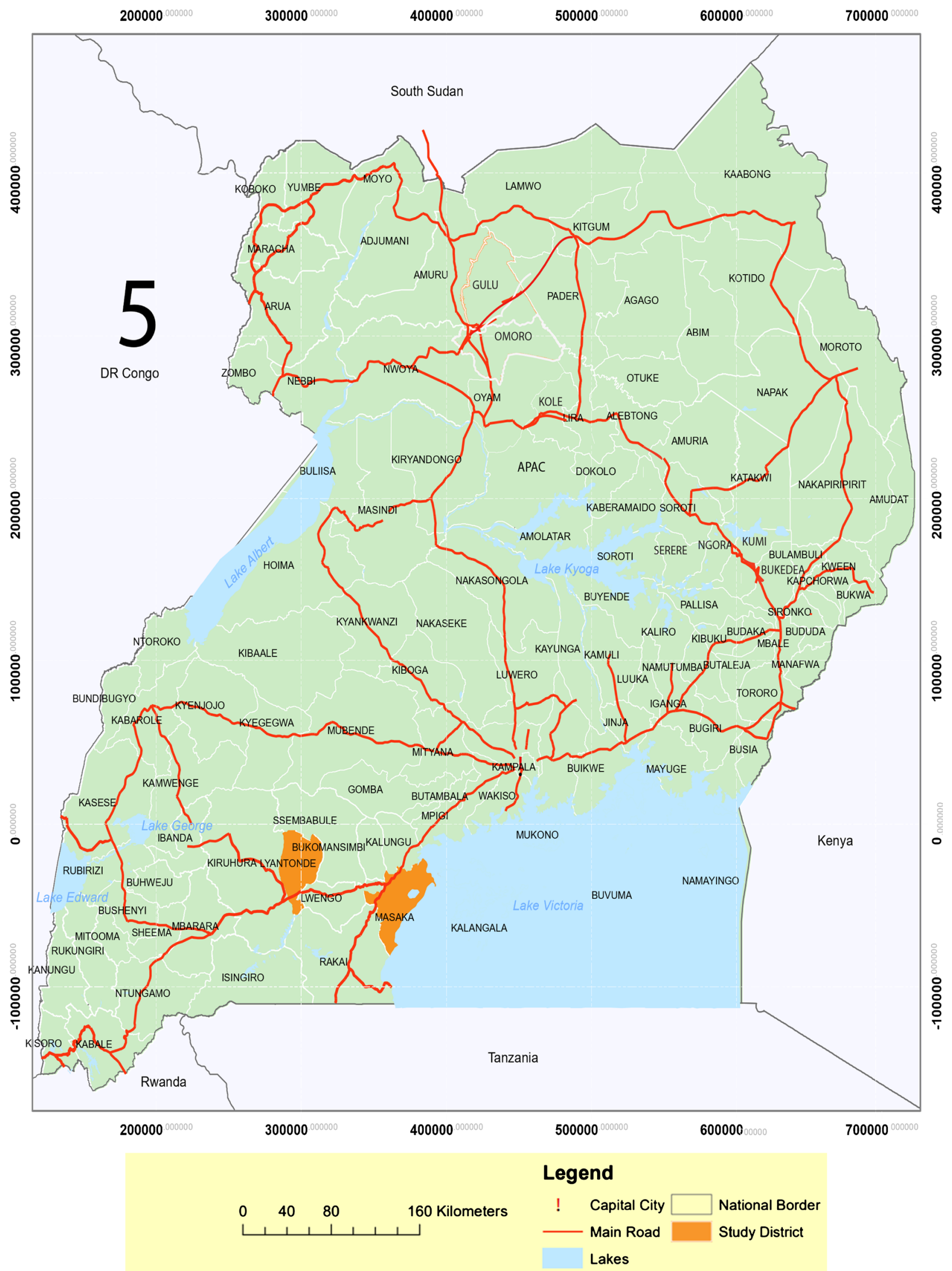

Figure 1. Map of Uganda showing position of Masaka and Lyantonde Districts. 


\section{Adapted from UBOS}

\subsection{Sampling Procedure}

Before the survey, stratification of respondents basing on administrative units (Districts, Sub-county, Parish and Village) was done. Samples were purposively taken from the strata (Sub-counties and villages) [18]. The purpose was to study villages with a higher number of SHFs. At village level, SHFs were randomly selected.

\subsection{Data Collection}

Using a Cross sectional survey, we obtained approval letters from Uganda Martyrs University. We consulted production officers at each District to purposively identify Sub-counties, Parishes and Villages with the highest number of Smallholder farmers. While at each village, local leaders identified names of all SHFs and a list was recorded. To eliminate bias and so reduce the error, names of each farmer were written separately on a piece of paper, put in a box, shaken and 30 names were randomly selected per village. A list of SHFs to be sampled was written down. We started distributing questionnaires with the help of one local council leader. A Respondent Identification Form was filled as questionnaires were delivered to potential respondents. We stopped surveying once we reached the twentieth responded from each village. Picking 30 papers was intended to create a reserve of respondents who would replace those that were not found at home at the time of the survey [17].

\subsection{Data Analysis}

In this study, preliminary data was analyzed in excel using descriptive statistics. Thus, frequency tables and charts were developed to provide simple summaries about the sample and related measurements. The quantitative data was then analyzed in SPSS starting with livestock and crop wastes followed by waste management methods and finally, factors affecting choice of waste management methods by SHFs. Responses of all farmers in a village were pooled together to get the overall score of the village, Sub-county and later District. Scores were converted to percentages by expressing each of them as a percentage fraction of the total. Correlation analysis was run in SPSS to determine any relationships among farm waste.

From the Pearson correlations run we could see that the correlation coefficients for all wastes was 0.969 to 0.995 which was non-significant $(\mathrm{P}>0.001$ for a two tailed test), based on 240 observations. For livestock wastes, when a multiple regression analysis was run, $\mathrm{P}=0.230, \mathrm{P}>0.05$. For crop waste, when a multiple regression analysis was run $\mathrm{P}=0.984, \mathrm{P}>0.05$.

From the Pearson correlations run we can see that the correlation coefficient for Composting, Surface deposition, Burning, Removal and Burry too small ranging from -0.088 to 0.045 , which is significant $(\mathrm{P}<0.05$ for a two tailed test), 
based on 240 observations. When a multiple regression analysis was run, $\mathrm{P}=$ $0.432, \mathrm{P}>0.05$.

Reward, Accessibility, Personal hygiene, Physical state and ownership had correlation coefficient values ranging between 0.0735 and 0.0828 at 0.05 significance level (2-tailed), ( $\rho>0.05)$. At 0.001 significance level (2-tailed), Ownership and Reward had a correlation coefficient of $-0.608(\rho<0.001)$, indicating a statistically significant linear relationship not to affect choice of WMP by SHFs. The rest of the factors (Age, Purpose, Season, Quantity of waste, Policy, Commitment, and Economic status), when correlated in SPSS showed $\rho<0.05$ at 0.05 significance level (2-tailed) thus their linear relationship considered non-significant.

\section{Results}

\subsection{Household Characterization}

Households in both areas accommodated both males and females with an average of 3:3. 65\% of the labor force was from the adults and $35 \%$ was from children below 18 years. 95\% of the SHFs were literate. The highest level of education attained was O-level certificate in Lyantonde and Diploma in Masaka. The lowest in both areas were illiterates at an average of $5 \%$. There is a mix of ethnic origins that categorizing them was not possible due to much intermarriage.

\subsection{Farm Characterization}

Smallholder farms were characterized by different attributes that were captured during the survey. These attributes were identified as: livestock kept included goats, cattle, pigs, sheep, rabbits and poultry. In Lyantonde, the average farm size was 3.6 acres. In Masaka average farm land was 2.9 acres. Average land under crops was 2.8 acres in Lyantonde while in Masaka it was 2.4 acres. Fallow land in Masaka was 0.4 acres on average while in Lyantonde it was 0.8 acres. Grazing land was 1.5 acres on average in Lyantonde while in Masaka it was 0.9 acres. The land tenure system in Masaka area was customary $85 \%$, hiring/leasing $10 \%$ and $5 \%$ on freehold. The land tenure system in Lyantonde area was customary $72 \%$, hiring/leasing $20 \%$ and $1 \%$ on freehold and $7 \%$ care takers. Major crops grown included legumes such as beans, peas, soya and nuts, bananas, cereals like maize, sorghum and millet vegetables such as tomatoes, eggplants, carrots, fruits such as mangoes, paw paws and guavas. The average numbers of livestock were: Cattle 1, Goats 2, Pigs 4 and Chicken 15.

\subsection{Farm Wastes}

A sample survey design was used. In Masaka District, data was collected from 120 SHF representing $10.1 \%$ of the total SHF population in the District while 120 SHF provided data from Lyantonde and this represented $17.4 \%$ of the total SHF in Lyantonde.

Results revealed that the most common livestock wastes in Lyantonde were: Goat slurry $20.4 \%$, Pig slurry $16.9 \%$, Poultry droppings $12.2 \%$ and cattle slurry 
the least at $11.2 \%$. In Masaka, the most common livestock wastes were: Pig slurry $23.6 \%$, Poultry $14.0 \%$, Cattle $12.9 \%$ and Goat slurry being the least at $11.1 \%$. The most common crop wastes in Lyantonde were: Bean trash 12.9\%, Maize trash $11.8 \%$, Banana leaves and peelings $11.2 \%$, and coffee leaves 3.1\%. In Masaka, common crop wastes were Banana leaves and peelings $11.1 \%$, Bean trash $10.6 \%$, Maize trash $8.9 \%$ and coffee leaves being the least at $7.8 \%$ (Table 2).

The regression equation for livestock waste is:

Livestock wastes $=7.966+0.147$ (Cattle slurry) -0.264 (Goat slurry) +0.085

(Pig slurry) - 0.054 (Poultry droppings).

The regression equation for crop waste is:

Crop wastes $=1.684-0.066$ (Coffee leaves) +0.234 (Banana leaves $)+0.050$ $($ Bean trash) +0.109 (Maize trash).

Testing the hypothesis: Ho: $\mu \mathrm{SWa}=\mu \mathrm{SWm}=0 . \quad \mathrm{SW}=$ System waste component (arable/mixed).

Ha: $\mu$ SWa $\neq \mu \mathrm{SWm} \neq 0$.

Data was analyzed at 0.05 significance level. At this level of significance, we were $95 \%$ confident that any difference noticed was due to type of farm waste (livestock waste: Poultry droppings, Goat slurry, Pig slurry and Cattle slurry; crop waste: Bean trash, Maize trash, Banana leaves and peelings and coffee leaves). For livestock wastes $\mathrm{P}=0.230, \mathrm{P}>0.05$ while for crop wastes, $\mathrm{P}=0.984$, $\mathrm{P}>0.05$. This is enough evidence to fail to reject the null hypothesis.

\subsection{Waste Management Practices}

In Lyantonde, smallholder farmers reported use waste management practices and frequencies of the most common were recorded as: Surface deposition $41.2 \%$, Burning 18.4\% Composting 17.3\%, Burry 9.4\%, Removal 10.9\% and Recycle $2.8 \%$. In Masaka, smallholder farmers reported use of the same practices and frequencies of the most common were recorded as: Surface deposition $40.9 \%$, Burning 18.6\% Composting 13.2\%, Burry 12.3\%, Removal 6.2\% and Recycle

Table 2. Farm wastes.

\begin{tabular}{|c|c|c|c|}
\hline \multirow{2}{*}{\multicolumn{2}{|c|}{ Waste category }} & \multicolumn{2}{|c|}{$\begin{array}{c}\text { Frequency of mention of waste } \\
\text { composition by SHF (\%) }\end{array}$} \\
\hline & & Lyantonde & Masaka \\
\hline \multirow{4}{*}{ Common livestock wastes } & Goat slurry & 20.4 & 11.1 \\
\hline & Pig slurry & 16.9 & 23.6 \\
\hline & Poultry droppings & 12.2 & 14 \\
\hline & Cattle slurry & 11.5 & 12.9 \\
\hline \multirow{4}{*}{ Common crop wastes } & Bean trash & 12.9 & 10.6 \\
\hline & Maize trash & 11.8 & 8.9 \\
\hline & Banana leaves and peelings & 11.2 & 11.1 \\
\hline & Coffee leaves & 3.1 & 7.8 \\
\hline
\end{tabular}


Table 3. Waste management practices.

\begin{tabular}{ccc}
\hline \multirow{2}{*}{ Practices } & \multicolumn{2}{c}{ Percentage of Smallholder farmers Using the practices (\%) } \\
\cline { 2 - 3 } & Lyantonde & Masaka \\
\hline Surface deposition & 41.2 & 40.9 \\
Burning & 18.4 & 18.6 \\
Composting & 17.3 & 13.2 \\
Burry & 9.4 & 12.3 \\
Removal & 10.9 & 6.2 \\
Recycle & 2.8 & 8.8 \\
& $100 \%$ & $100 \%$ \\
\hline
\end{tabular}

\section{$8.8 \%$ (Table 3).}

Unstandardized Coefficients were used to develop the Regression equation stated as:

Waste management Practices $=-15.116+1.223$ (Composting) +0.570 (Surface deposition) +0.926 (Burning) +0.488 (Removal) +0.96 (Burry)

Testing the hypothesis:

Ho: $\mu \mathrm{MPa}=\mu \mathrm{MPm}=0 . \quad \mathrm{MP}=$ Waste management practice $($ arable $/$ mixed $)$.

Ha: $\mu \mathrm{MPa} \neq \mu \mathrm{MPm} \neq 0$.

Data was analyzed at 0.05 significance level. At this level of significance, we were $95 \%$ confident that any difference noticed was due to Waste Management Practices (Burry, Removal, Composting, Burning and Surface deposition). $\mathrm{P}=$ $0.432, \mathrm{P}>0.05$. This is enough evidence to fail to reject the null hypothesis.

\subsection{Factors Determining SHF's Choice of Waste Management Practice}

In Lyantonde, SHF reported the following factors to be major determinants of waste management practices in their area. The factors and their proportions were as follows: $8.7 \%$ reported age, $6.1 \%$ Purpose of waste product, $4.1 \%$ accessibility of their fields, $13.6 \%$ season, $7.9 \%$ Physical state of the waste, $17.2 \%$ Quantity of the wastes, 1.5\% Personal hygiene of the farmer, 5.3\% Associated rewards during or after waste management, $7.1 \%$ Ownership of the farm, 1.3\% Waste management policy awareness, 15.9\% Farmer's commitment and 11.3\% Economic status of the farmer (Table 3).

In Masaka SHF reported the following factors to be major determinants of waste management practices in their area. The factors and their proportions were as follows: $7.2 \%$ reported age, 9.2\% Purpose of waste product, $9.8 \%$ accessibility of their fields, 6.4\% season, 9.5\% Physical state of the waste, 14.4\% Quantity of the wastes, $2.9 \%$ Personal hygiene of the farmer, $10.9 \%$ Associated rewards during or after waste management, $2.9 \%$ Ownership of the farm, $1.6 \%$ Waste management policy awareness, 15.4\% Farmer's commitment and 9.8\% Economic status of the farmer (Table 4). 
Table 4. Factors determining SHF's choice of waste management practice.

\begin{tabular}{ccc}
\hline Determining Factors & $\begin{array}{c}\text { Frequency of mention by } \\
\text { SHF in Lyantonde (\%) }\end{array}$ & $\begin{array}{c}\text { Frequency of mention } \\
\text { by SHF in Masaka (\%) }\end{array}$ \\
\hline Age & 8.7 & 7.2 \\
Purpose of Waste & 6.1 & 9.2 \\
Accessibility to the garden & 4.1 & 9.8 \\
Season & 13.6 & 6.4 \\
Physical state of waste & 7.9 & 9.5 \\
Quantity of waste & 17.2 & 14.4 \\
Personal hygiene & 1.5 & 2.9 \\
Associated reward & 5.3 & 10.9 \\
Ownership of the farm & 7.1 & 2.9 \\
Waste management Policy awareness & 1.3 & 1.6 \\
Farmer's commitment & 15.9 & 15.4 \\
Economic status & 11.3 & 9.8 \\
\hline
\end{tabular}

Unstandardized Coefficients were considered to develop the Regression equation stated as:

Factors for WMP $=5.613+0.045$ (Age) +1.528 (Season) +0.415 (Quantity) 4.942 (Policy) - 1.088 (Commitment) +3.935 (Economic status) - 4.470 (Purpose). Therefore, application of any waste management practice was associated with a change of 5.613 in SHF's choice assuming other factors constant.

Testing the hypothesis;

Ho: $\mu \mathrm{MFa}=\mu \mathrm{MFm}=0 . \quad \mathrm{MF}=$ Waste management factors (arable $/$ mixed).

Ha: $\mu \mathrm{MFa} \neq \mu \mathrm{MFm} \neq 0$.

Data was analyzed at 0.05 significance level. At this level of significance, we were $95 \%$ confident that any difference noticed was due to factors affecting choice of WMP by SHFs (Purpose, Quantity, Policy, Commitment, Age, Season, and Economic status) and not a result of chance, $\mathrm{P}=0.045, \mathrm{P}<0.05$. This is enough evidence to reject the null hypothesis.

\section{Discussion}

Despite the social economic differences among farmers in Masaka and Lyantode, farmers in both systems generated crop and livestock wastes in varying quantities. The fact that smallholder farmers tend to share some characteristics in common such as dependence on family labor and use of on-farm inputs among others, there was no farmer identified with capacity or technologies to separate urine from dung, thus all of them reported slurry (goat, cattle and pig slurry).

Many SHFs own goats and pigs even when they live in the cattle corridor. This is because cattle are expensive type of livestock to purchase, house and feed especially in terms of securing grazing land for it. Lyantonde has land pressure from rich commercial farmers backed up by anonymous agents that have cur- 
rently denied the poor stallholder farmers to access land that is big enough for cattle rearing. As an alternative these SHF resort to small ruminants such as goats and others go for poultry and pigs. These can be kept on small pieces of land and mature faster. This justifies the type of animal wastes they produce. Lack of sufficient technologies and skills are among the reasons why these materials remain redundant on their farms and thus regarded or disposed of as wastes. Some of these would be more productive for example slurry would be helpful in production of biogas! To the arable SHFs, absence of livestock such as pigs and goats rendered these farms more prone to accumulated crop wastes because such animals would feed on these crop wastes if they were available on the farms.

Land tenure systems across the country do not advantage SHFs, instead limits them on the type of crops/livestock to manage hence influencing the type of wastes to be produced. The land tenure system of care takers does not promote farmer innovation to manage waste. This is because the farmer in not the owner of the farm and expects to move away any time. This leads to accumulation of wastes. Also intensive grazing systems contribute to the accumulation of wastes in particular farms as opposed to those with free range systems. Accumulation would not be a problem if subsequent waste management functions such reduction and re-use were operational.

SHFs oscillate usage of waste management practices onto individual and or a mixture of farm wastes. Though none mentioned so, but results indicate surface deposition to be a default waste management practice (disposing for convenience). Off-farm factors such as commercial buyers of some wastes like livestock slurry greatly influenced SHF's waste management practices. In such scenarios, rewards were key to promote sorting, storage and transportation of waste to places away from the farm. The hard to sell waste or otherwise wastes needed at the farm for some reason were subjected to any appropriate practice. These included: Surface deposition, Burning Composting, Burry, Removal and Recycle. In Lyantonde for example, $73 \%$ of the SHF reported burning bean trash to eliminate its "infertility properties". Science does not recommend this; and more so bean trash have a leguminous origin.

Despite the global challenge of waste related problems, SHFs were at liberty to do anything in any way to their waste. This was evidenced by the low frequency of farmers' awareness on waste management policies. Before the study we anticipated to find some organized systems responsible to guide farmers on farm waste management. To the farmers, it was not a regulated system approach that determined which practice to be used, instead choice was based on convenience and farmer commitment which [19] also reported in Ghana to be a major factor that accounted for sorting of waste. Such conveniences like quick disposal, abandoning and burning suffocated good practices of waste management. For SHFs who managed their farm wastes so well, the magnitude of each of these factors varied with overlaps for a particular choice to be undertaken. 


\section{Conclusions}

The farm waste (livestock waste: Poultry droppings, Goat slurry, Pig slurry and Cattle slurry) and crop waste (Bean trash, Maize trash, Banana leaves and peelings and coffee leaves) were identified as major farm wastes in both farming Districts. The fact that SHFs in Lyantonde reported burning bean trash due to "its infertility properties" poses a big question for research to answer.

Waste Management Practices that were recorded included: Burry, Removal, Composting, Recycle, Burning and Surface deposition. Of all these practices, Composting and Recycle are the globally recommended sustainable practices. The practices of Burry, Removal, Burning and Surface deposition are not sustainable in terms of nutrient balance and are responsible for more GHG emissions to the environment. Factors affecting choice of Waste Management Practices by SHFs included Purpose, Quantity, Policy, Commitment, Age, Season, and Economic status.

\section{Recommendations}

SHFs are urged to use appropriate WMP that can adequately reduce, remove or recycle wastes while mitigating GHG emissions. Further studies were recommended to estimate GHG emissions from individual wastes or farming systems and the efficacies of these WMP to mitigate or to emit GHGs. Lastly, measures should be put in place to implement practices that are environmentally safe such as composting and recycling.

\section{Acknowledgement}

We acknowledge Matovu Samuel Mbogo (Rev), Mr. Ssagala David, Mwine Julius (Prof), ACALISE of Uganda Martyrs University and NTNU-Norway for their support.

\section{Funding}

This work was funded by World Bank through ACALISE of Uganda Martyrs University, Uganda.

\section{Conflicts of Interest}

The authors declare no conflicts of interest regarding the publication of this paper.

\section{References}

[1] Gustavsson, J., Cederberg, C. and Sonesson, U. (2011) Global Food Losses and Food Waste: Extent, Causes and Prevention. Study Conducted for the International Congress Save Food! At Interpack, Düsseldorf, Germany. Food and Agriculture Organization of the United Nations, Rome.

http://www.fao.org/fileadmin/user_upload/suistainability/pdf/Global_Food_Losses and_Food_Waste.pdf

[2] Fehr, A., Urushadze, T., Zöller, N., Knerr, B., Ploeger, A. and Vogtmann, H. (2020) 
Establishing a Sustainable Waste Management System in a Transitional Economic Context: Analysis of the Socio-Economic Dynamics. Sustainability, 12, Article No. 3887. https://doi.org/10.3390/su12093887

[3] En, S. and Sabiiti, E. (2011) Utilising Agricultural Waste to Enhance Food Security and Conserve The Environment. African Journal of Food, Agriculture, Nutrition and Development, 11, 1-9.

[4] Friedlingstein, P., et al. (2019) Global Carbon Budget 2019. Earth System Science Data, 11, 1783-1838. https://doi.org/10.5194/essd-11-1783-2019

[5] Sánchez, A. et al. (2015) Greenhouse Gas Emissions from Organic Waste Composting. Environmental Chemistry Letters, 13, 223-238.

https://doi.org/10.1007/s10311-015-0507-5

[6] Tubiello, F.N., Cóndor-Golec, R.D., Salvatore, M., Piersante, A. and Federici, S. (2015) Estimating Greenhouse Gas Emissions in Agriculture-A Manual to Address Data Requirements for Developing Countries. FAO, Rome.

http://www.fao.org/documents/card/en/c/1a92660d-5e84-4686-86ad-f338fa9e58aa/

[7] Fagerström, A. et al. (2018) The Role of Anaerobic Digestion and Biogas in the Circular Economy.

https://www.ieabioenergy.com/wp-content/uploads/2018/08/anaerobic-digestion_w eb_END.pdf

[8] Thompson, S. (2005) Modeling Waste Management Options for Greenhouse Gas Reduction. Journal of Environmental Informatics, 6, 16-24.

https://doi.org/10.3808/jei.200500051

[9] Pongracz, E. (2006) Industrial Ecology and Waste Management: From Theories to Applications. Progress in Industrial Ecology, An International Journal(PIE), 3, 59-74. https://doi.org/10.1504/PIE.2006.010041

[10] Obi, F., Ugwuishiwu, B. and Nwakaire, J. (2016) Agricultural Waste Concept, Generation, Utilization and Management. Nigerian Journal of Technology, 35, 957-964. https://doi.org/10.4314/njt.v35i4.34

[11] Pongrácz, E., Phillips, P.S. and Keiski, R.L. (2004) Evolving the Theory of Waste Management: Defining key Concepts. Progress in Industrial Ecology-An International Journal, 3, 59-74.

[12] Nabavi, R.T. (2012) Bandura's Social Learning Theory \& Social Cognitive Learning Theory. Journal of Personality and Social Psychology, 1, 589.

[13] (2016) Uganda Climate Action Report for 2015. https://www.irishaid.ie/media/irishaid/allwebsitemedia/30whatwedo/climatechange /Uganda-Country-Climate-Action-Reports-2016.pdf

[14] Herrero, M., et al. (2010) Smart Investments in Sustainable Food Production: Revisiting Mixed Crop-Livestock Systems. Science, 327, 822-825.

https://doi.org/10.1126/science.1183725

[15] Kinati, W. and Mulema, A.A. (2019) Gender Issues in Livestock Production in Ethiopia. Journal of Livestock Science, 10, 66-80.

[16] Mugisa, D.J., Katimbo, A., Sempiira, J.E. and Kisaalita, W.S. (2016) Anthropometric Characteristics of Female Smallholder Farmers of Uganda-Toward Design of LaborSaving Tools. Applied Ergonomics, 54, 177-185.

https://doi.org/10.1016/j.apergo.2015.12.010

[17] Nsimbe, P., Mendoza, H., Wafula, S.T. and Ndejjo, R. (2018) Factors Associated with Composting of Solid Waste at Household Level in Masaka Municipality, Central Uganda. Journal of Environmental and Public Health, 2018, Article ID: 1284234. 
https://doi.org/10.1155/2018/1284234

[18] Omona, J. (2013) Sampling in Qualitative Research: Improving the Quality of Research Outcomes in Higher Education. Makerere Journal of Higher Education, 4, 169-185. https://doi.org/10.4314/majohe.v4i2.4

[19] Miezah, K., Obiri-Danso, K., Kádár, Z., Fei-Baffoe, B. and Mensah, M.Y. (2015) Municipal Solid Waste Characterization and Quantification as a Measure towards Effective Waste Management in Ghana. Waste Management, 46, 15-27.

https://doi.org/10.1016/j.wasman.2015.09.009 